\title{
Celebrity Cake Branding as the Initiators of Nowadays Cake
}

\section{Branding Kue Selebritis sebagai Pelopor Kue Kekinian}

\author{
Rostika Yuliani ${ }^{1}$, Susanne Dida ${ }^{2}$, Nisa Eka Nastiti ${ }^{3}$ \\ 1,2,3 Universitas Padjadjaran, Jatinangor, Jawa Barat \\ rostika.yuliani@gmail.com
}

\begin{abstract}
The development of business culinary in Bandung city invited Indonesian national celebrities to invest in cake shops. Laudya Cynthia Bella, with her Bandung Makuta, and Ananda Omesh, with his Bandung Kunafe, were the initiators. The research aimed to assimilate the branding methods of Bandung Makuta and Bandung Kunafe as nowadays cakes. The research used a combination between a qualitative method and a study-case approach. The data was collected by performing interviews, observation, literature review, and online data gathering. The research found that branding activity run by Bandung Makuta and Bandung Kunafe in the form of advertising, marketing, public relations, and special events was considered successful in making residents and tourists of Bandung visit Bandung city and purchase the products. Taglines \#initehngangenin (\#itismemorable) and \#lembutpisaneuy (\#itisalsomoist) promoted by Bandung Makuta and Bandung Kunafe, respectively, triggered the customers to be more intrigued by the products. The research recommended that Bandung Makuta and Bandung Kunafe start to innovate and modify their products, notably the form, taste, and package.
\end{abstract}

Keywords: Bandung Kunafe; Bandung Makuta; Branding; Celebrity Cake

\begin{abstract}
Abstrak
Perkembangan bisnis yang semakin maju terutama bisnis kuliner di Kota Bandung mengakibatkan banyak kalangan artis berlomba untuk membuka bisnis kue kekinian dan salah satunya adalah Laudya Cynthia Bella yang merupakan pelopor pertama kue kekinian di Kota Bandung dengan Brandnya yaitu Bandung Makuta dan Ananda Omesh merupakan pelopor kue Bandung Kunafe. Tujuan penelitian ini adalah untuk mengetahui cara branding Bandung Makuta dan Bandung Kunafe sebagai kue kekinian kepada masyarakat. Metodologi Penelitian ini dilakukan dengan menggunakan metodologi penelitian kualitatif dengan pendekatan studi kasus.Instrumen penelitian yang digunakan adalah wawancara, observasi, studi pustaka dan penelusuran secara online. Hasil penelitian menunjukan bahwa branding yang dilakukan oleh Bandung Makuta dan Bandung Kunafe ini dilakukan dengan cara advertising, marketing, public relations,special events yang dinilai sukses membuat masyarakat dan wisatawan yang berkunjung ke Kota Bandung tertarik untuk membeli Bandung Makuta berkat tagline \#initehngangenin dan tagline \#lembutpisaneuy yang membuat masyarakat semakin penasaran akan produk dari Bandung Makuta dan Bandung Kunafe tersebut. Rekomendasi yang diberikan adalah perlu adanya inovasi terbaru dari produk bandung makuta dan bandung kunafe baik itu dari segi bentuk, cita rasa ataupun kemasan.
\end{abstract}

Kata Kunci: Bandung Kunafe; Bandung Makuta; Branding; Kue Selebritis 


\section{Introduction}

Coupled with the business competition that is being stiffer and the development of communication and information technology that is being more cutting edge, the number of entrepreneurs competing to run culinary business, especially cake, in Bandung city is proliferated. Not only do the general entrepreneurs strive for this type of business, but also celebrities. The reason probably is the development in this market, in addition to the side income and the potency in prolonging their popularities by taking advantage of celebrity branding.

Bandung is well-known as a culinary destination, whether for domestic or international tourists, apart from the status as one of the most prominent Indonesian cities. After the supports coming from the mayor of Bandung itself, Ridwan Kamil, that stated that "culinary festivals in Bandung will be multiplied to support its new brand as the national culinary destination," the trend in culinary and cake business grows significantly. The mayor support motivates many celebrities to take the opportunities to open cake shops in Bandung.

One of the culinary business, especially cake, opening in Bandung is Bandung Makuta. It is one of the initiators of celebrity cake and was launched by Laudya Cynthia Bella, a national celebrity, for the first time on March 17, 2017. Bandung Makuta is under the management of Janah Corp, a joint venture of stars that see significant opportunities in cake industries, and, currently, it is one of the most wanted cakes and iconic food souvenirs from Bandung. The popularity has reached not only tourists of Bandung but also the residents of Bandung itself. Nevertheless, apart from Bandung Makuta, Bandung is also replete of other cake shops. The list can be seen in the table below:

Table 1. List of celebrities that own cake shops in Bandung

\begin{tabular}{ll}
\hline Product name & Celebrity's owner \\
\hline Bandung Princess Cake & Syahrini \\
\hline Pevo Cake & Pevita Pearce \\
\hline Madinah Cake & Angel Lelga\& Vicky Prasetyo \\
\hline Bandung Kunafe & Irfan Hakim dan Ananda Omesh \\
\hline Ceata Cake & Cita Citata \\
\hline Bandung Kanaya & Ibunda Raffi Ahmad, Ami Qanita \\
\hline Vincake & Vino G Bastian \\
\hline Kuenya Ayu & Ayu Tingting \\
\hline & source: observation, August 23, 2018
\end{tabular}

Bandung Makuta is one of the first brandings of nowadays cake in Bandung. The figure of Laudya Cynthia Bella that originally comes from Bandung, undeniably, plays a significant role in it. Together with Bandung Makuta, Laudya Cynthia Bella tries to give innovation, and even "crown," for Bandung. One of her intention to step to this business is to conduct a meet and greet with her fans in her shops. In addition to owned by Laudya Cynthia Bella, this shop becomes the favorite and star of Bandung arguably because of the specialty of Bandung Makuta in making cakes with three layers of texture. The first layer is puff pastry, the second layer is brownies, and there is heavy cream that tastes like milk pudding in the last layer. Indeed, in terms of price, Bandung Makuta is considered affordable for tourists and Bandung people. The price list can be seen in the table below: 
Table 2. Price list of Bandung Makuta's product

\begin{tabular}{lll}
\hline No & Product name & Price \\
\hline 1 & MAKUTA BLUEBERRY & Rp. 61.364 \\
\hline 2 & MAKUTA CHEESE & Rp. 61.364 \\
\hline 3 & MAKUTA CARAMEL & Rp. 61.364 \\
\hline 4 & MAKUTA LEMON & Rp. 61.364 \\
\hline 5 & MAKUTA CHOCOLATE & Rp 61.364 \\
\hline 6 & MAKUTA EXTRA CHEESE & Rp. 66.364 \\
\hline 7 & MAKUTA CHOCO CHEESE & Rp. 71.364 \\
\hline 8 & MAKUTA CASSAVA CHEESE / & Rp. 71.364 \\
\hline 9 & PEUYEUM \\
\hline
\end{tabular}

The meaning of Bandung Makuta is "mahkota" (crown), and by that name, the shop is wished to be the crown and icon of Bandung. Furthermore, by that name, they hope that their shops will be remembered every time tourists recall Bandung, or simply as shops that are attached to Bandung. Since the establishment on March 17, 2017, Bandung Makuta has gained numerous visitors. Indeed, it is frequently found that tourists and Bandung residents have to wait for a long time in a line to purchase and taste Bandung Makuta. In general, $80 \%$ of the customers of Bandung Makuta are non-Bandung residents, and $1 \%$ are from non-Indonesia citizens, such as Singapore and Malaysia. The rest $18 \%$ is from Bandung. Friday, Saturday, and Sunday are the busiest days. The logo of Bandung Makuta can be seen in the picture below:

Figure 1. Bandung Makuta's brand

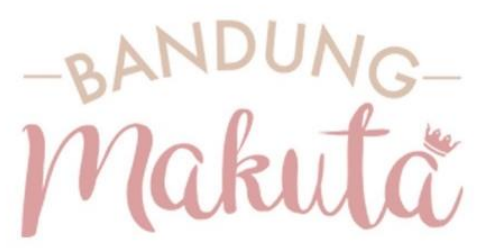

source: Bandung Makuta's website

Bandung Makuta has five stores in Bandung, in Van de Venter Street No. 2, Arjuna Street No. 15, Popup Store Mall 23 Pascal, in Ir. H. Juanda Street (Dago) No. 138, and Dr. Djunjunan street (Pasteur) No. 139. The branding of Bandung Makuta has gained positive responses, and even Rendra Sudjono, a famous presenter, gave a testimonial on Bandung Makuta: "the taste of Makuta Cheese is delicious. The cheese is melted on my tongue." As a nowadays cake, Bandung Makuta open not only offline stores that are spread in 5 places in Bandung but also open accounts on social media, such as Instagram and Facebook, which successfully manage many followers and likers, including tourists. The user name of Bandung Makuta on Instagram is @ BandungMakuta, whereas its Facebook account is Bandung Makuta Café. The followers and likers of Bandung Makuta are more significant than other celebrity brands. The differences can be seen in the table below: 
Table 3. Number of followers \& likers of Bandung nowadays cake on social media

\begin{tabular}{clll}
\hline No & \multicolumn{1}{c}{ Product name } & \multicolumn{1}{c}{ Instagram's follower } & \multicolumn{1}{c}{ Facebook's likers } \\
\hline 1 & Bandung Makuta & 365.000 & 59.689 \\
\hline 2 & Bandung Princess Cake & 105.000 & 16.065 \\
\hline 3 & Pevo Cake & 18.700 & 71 \\
\hline 4 & Madinah Cake & 12.100 & 1428 \\
\hline 5 & Bandung Kunafe & 103.000 & 28.916 \\
\hline 6 & Ceata Cake & 235 & 403 \\
\hline 7 & Bandung Kanaya & 39.700 & 1.282 \\
\hline 9 & Vincake & 6.215 & 4.424 \\
\hline 10 & Kuenya Ayu & 145.000 & 2.084 \\
\hline
\end{tabular}

Indeed, Bandung Makuta has its tagline, namely \#initehngangenin (\#itismemorable). It is intended to make Bandung Makuta be a reason for Bandung residents and tourists of Bandung to miss Bandung culinary. It is worth noting that Bandung Makuta does not market its shops through marketing strategy only, but also through advertising, event, and public relations, including special event and charities so that the number of people who are familiar with Bandung Makuta, as nowadays cake, and representation or "crown" of Bandung, can grow.

However, with the recent advent of other celebrity cake shops that massively compete to establish cake business in Bandung and introduce more varieties of tastes and products, including unique name, tagline, and package, of celebrities branding, especially in terms of cake shops, the rivalry in this industry for Bandung Makuta is being more intense. Out of many new cake shops, another prominent celebrity cake shop worth considering is Bandung Kunafe.

Bandung Kunafe is owned by another celebrity, Ananda Omesh, and was established on October 21, 2017. The tagline of the shop is \#dinginlebihnikmat (\#coolistastier), and this shop sells many types of cakes, ranging from Kunafe Cheese, Blueberry Cheese, Choco Cheese, Choco Fiesta, Chocolate, Durian, Tiramisu, and Green Tea. This cake shop emphasizes the texture of the Kunafe cake that is tender and cool. This characteristic is arguably different from other celebrity cakes in the market. The word "kunafe" is a slang adapted from Sundanese Language, "kunaon," which means "asking a question."

Besides \#coolistastier, another tagline of Bandung Kunafe is \#itisalsomoist (lembutpisaneuy). The reason behind that tagline is to remind the customers that Bandung Kunafe's cakes are moist as Bandung residents, who are humble and kind. The price list of the cakes in this shop is around Rp68.000-Rp75.000. Also, Bandung Kunafe sells merchandise and Kunage's t-shirt. A tote bag is around Rp5.000-Rp9.000 while a t-shirt it is around 25.000-35.000. The logo of Bandung Kunafe can be seen below:

Figure 2. Bandung Kunafe's logo

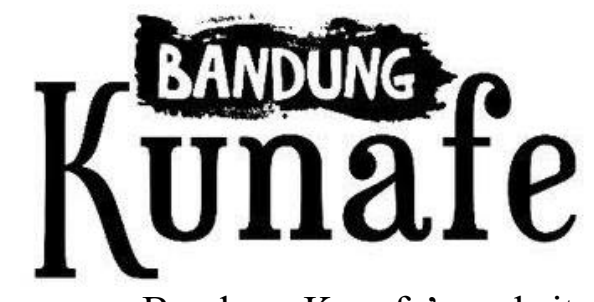

source: Bandung Kunafe's website 
Branding is an attempt that is included in the marketing sector. Many sources state that a brand is a name, logo, symbol, and other entities that can help the people to identify a business. Branding is not only essential for conventional business but also for a startup. Moreover, it is very significant for the latter since they should introduce the companies quickly, both for the service they offer and for their name to be well-acquainted. Consider branding performed by "Usaha Dapoer Rendang Riry" as an example. A study conducted by Wulandari (2018) found that the branding of that business mentioned highly figured in maximizing, introducing, and convincing society, that its products were not only for the elderly but also for the youngster. The branding applied the principles and elements of visual communication, and the primary media to apply the method was Brand Guide Line, while the supporting media was the packaging, poster, $\mathrm{x}$-banner, $\mathrm{t}$-shirt, shopping bag, sticker, stationery sets, and apron. Not to mention that this shop was also available on Instagram and Facebook.

However, different from previous studies, Bandung Makuta's brand cannot be separated from Laudya Cynthia Bella, who, in addition to Bandung's resident, always promote Bandung Makuta's product to Bandung's residents and tourists visiting Bandung. Similarly, Bandung Kunafe cannot be distinguished from the status and role of Anada Omesh that is also from Bandung. Furthermore, on social media, including Instagram and Facebook, they, as the owners, do not only sell their products but also show their activity during interacting with the customers. The research aims to understand methods conducted by Bandung Makuta and Bandung Kunafe in branding their nowadays cakes to society.

\section{Methodology}

The research was qualitative research that used a case-study as the approach. As regards a case-study (Cresswell, 2015), it can be defined as a qualitative study that explores a real-life on a limited system from any cases through detail and careful data collection that involves various sources of information or compound information, such as observation, interviews, audiovisual material, documents and reports; and report the description of the case and theme of the case. According to Elvinaro (Elvinaro, 2016), a case study provides evidence about an individual. The individual is usually a human, but it can also be a place, such as a school, company, or surrounding.

The instruments used were interviews, observations, literature review, and online data gathering. In the interviews, the informants were the manager of sales and marketing, and supervisor of Bandung Makuta, as well as consumers of Bandung Makuta and Bandung Kunafe. Furthermore, non-participative observations and literature review on communication theories and other supporting theories in the books and journals on branding, which can elucidate the main problems of the research, were conducted to supplement the primary information. The other method was online data gathering by reviewing the Bandung Makuta's and Bandung Kunafe's accounts on Instagram and Facebook.

\section{Results and Discussion}

Culinary business is an Indonesian developing business today. The appearance of many different foods, culinary places, and trends as the lifestyle, are signs of the significant growth of this sector. In the era when the interest in culinary business is increasing, many celebrities open their culinary business, especially cake, to Bandung. It 
is expected that their shops become the center of food souvenirs in Bandung, whether for the residents of Bandung or the tourists.

Perbawasari (2016) pointed out that presentness is a trend that was booming or popular since people are following the trend. The nowadays trend that is developed and used will change and even not be used anymore in the future. Subsequently, new measures will appear. In line with that, Susanto (2017) contended that the development of culinary business initiated by some celebrities is a new phenomenon in which the celebrity itself, the brand ambassador, is designed to be the most attractive point of the sale. This development cannot be separated from social media as the promotion channel of celebrities. There are two general methods presented by the celebrities: firstly, by including the name of the region in the name of the product, such as Bandung Makuta, and, secondly, by not attaching any region name. For example, Gigeat Cake, a cake shop that had several branches and put Nagita Slavina and Rafi Ahmad as the ambassador, did not use the name of a region.

For Keller (2017), branding is a technique used by the culinary industry to create a recognizable image to attract consumers and increase sales. Furthermore, according to Levine (2003: 6), there are three components in performing branding, namely advertising, marketing, and public relations. As for advertising, it is a form of non-personal presentation and promotion of an idea, product, or service, that is not free, and the identified sponsorship company executes it. The characteristic of the advertisement is non-personal and one-way. Sometimes, there are public advertisements that aim and care to transform people's behavior and attitudes.

The researcher found that Bandung Makuta's products owned by Laudya Cynthia Bella and Bandung Kunafe's product owned by Ananda Omes were the first nowadays cakes initiated by celebrities that had a specialty in terms of packaging, taste, and shop's concepts. Based on online data gathering, Bandung Makuta used advertising on many platforms, such as Instagram and Facebook, whereas for printed media, billboard, banner, and $\mathrm{x}$ banner, were preferred. Besides, Bandung Makuta also re-branded 30 cars of online transportations by putting a full-body sticker on it. The picture below shows one of the designs of the Bandung Makuta's banner.

Figure 1.3 Bandung Makuta's banner

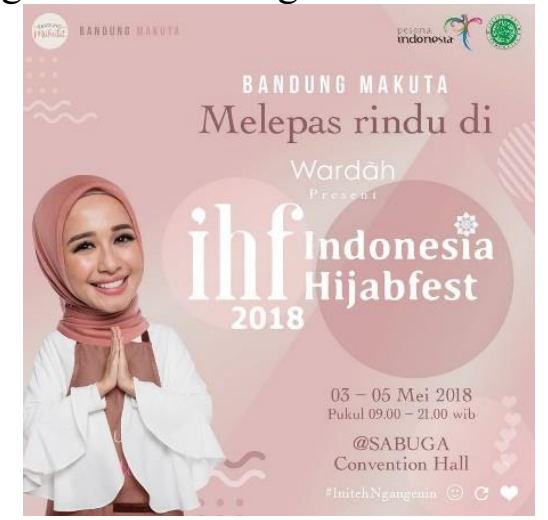

source: Researcher's documentation \& Bandung makuta's Instagram

For marketing, Bandung Makuta performed personal selling by executing twoway communication. To realize it, the staff explained the features of the brand, which might be suitable for the interests of the customers. This measure was available in all Bandung Makuta stores. The official Line of Bandung Makuta (@bandungmakuta) also 
supported the method of approaching customers. With those two activities, Bandung Makuta expected that the customers could interact more comfortably with the stores. Not only with the cashier but also with the admin of official accounts on social media.

Bandung Makuta used four media social to execute its interactive marketing with the customers. Besides Line, Bandung Makuta was also available on Instagram, Facebook, and YouTube. Those social media were chosen since it was suitable with the market segmentation and target market of Bandung Makuta, namely generation $\mathrm{Y}$ (Millenial) and Z. Particularly for Instagram and Line, the consideration was the high engagement of those generations with the social media mentioned. Therefore, based on the specialty of social media, Instagram was preferred for visual promotion while Line was managed for information dissemination regarding marketing. Facebook was used because many of the customers were still using Facebook, while YouTube was used to share documentation video of marketing activities.

Regarding social media use on marketing, the strategy seems suitable to a study conducted by Ratriyana (2019). Her study on a local brand in fashion, especially Amazara that had a high rate of equity, found that a high engagement and sale in fashion was associated with brand awareness, brand equity, brand association, and brand loyalty. In that vein, the role of social media was considerably influential in supporting local brands, including Amazara, in Millenial's perspective. Compared to other methods, the decision to maximalize social media and events was in line with Raniwati's study (2017) on word of mouth in purchasing clothes with Batik type in Bangkalan. For her, a method like word of mouth is not influential in customer decision to buy a product, apart from the fact the social perception and awareness also gave a significant influence. The reason is that word of mouth only discusses, promotes, and recommends the product without inviting and encouraging the interlocutor to purchase something, which, in this case, batik.

As for public relations, one of Bandung Makuta's activities was clarifying issues appearing about Bandung Makuta. For example, when there was a scalper that sold Bandung Makuta's food using Go Food (an online food delivery application) by making fake receipts, the public relations division of Bandung Makuta immediately clarified the issue. The issue was resolved by making an official delivery service from the stores. Publicity by seeking online news regarding Bandung Makuta was also part of public relations work.

Another activity worth noting was public events. One of the most favorite events of Bandung Makuta were events involving Laudya Cynthia Bella (Teh Bella). Besides an event named "Gathering with Teh Bella" for introducing the figure of Laudya Cynthia Bella to society, she was also involved in "Icalan" (Selling), an event when Laudya Cynthia Bella herself sold the products. "Tea-time with Laudya Cynthia Bella" was also the special event of Bandung Makuta since, in that event, the "Makuku" (the fans of Bandung Makuta) could enjoy talk show about women and business. Sometimes, that event also announced some programs, such as pop up store in Dr. Djunjunan No. 139, Pasteur, and food truck entitled "Kuralang Kuriling Ngangein." Indeed, this program had become more cheerful and memorable because the Makuku could also enjoy the new product, such as Green Tea Cheese.

What is more, the events of Bandung Makuta also tried to improve particular communities. For example, the last August, for celebrating the independence month of Indonesia, Bandung Makuta invited its followers to participate in the people competition held in August. Another community event was Tabligh Akbar (Islamic grand preach) that 
aimed to raise the religiosity and faith in Ramadhan month. The last Tabligh Akbar was held on Mei, 22, 2018, invited Ust. Evie Effendie, and it was held together with breakfasting with orphans. Bandung Makuta also conducted charity in the form of free public circumcision to assist families that were unfortunate economically, and grow sympathy in Bandung residents. Lastly, Bandung Makuta also had \#bandungnganeging, and Unboxing Makuta Gold Series.

Similarly, Bandung Kunafe was quite active in public relations activities. However, instead of duplicating the same events, the public relations division of Bandung Kunafe preferred to do a giveaway, post teaser video on the product, or promote through social media, such as Facebook and Instagram.

Lenka (2014) argued that public relations, in branding, figures in making narrative or conversation and medium supplier to facilitate conversation, such as by using social media. Besides, public relations figures in formulating strategic messages. For example, as described by Lovie (2015), Dunkin Donuts, with its 11.000 restaurants in 33 countries and 18 billion sales of coffee in a year, targets customers who loved to celebrate and be cheerful. Consequently, to support it, Dunkin Donuts used a name, logo, and colors to create visual branding on Instagram suitable to the brand.

Considering the three components in branding and the previous finding, the branding of Bandung Makuta and Bandung Kunafe, as nowadays cake, can be categorized as effective. It can be seen from the activities run by the public relation of Bandung Makuta and Bandung Kunafe. Their activities succeeded in making many residents and tourists of Bandung purchase their products. In this case, the effect of the tagline cannot be ignored.

In preserving the branding of Bandung Makuta's product, Bandung Makuta differentiated itself with the product, quality, service, cleanliness, and promotion. As for the product, the taste of Bandung Makuta was different from other products. It was also more significant and stable in terms of size since the outer layer was made from pastry ingredients. It enables the cake not to easily broken during the intercity trip. In terms of quality, the ingredient was from the best ingredients so as no to make the consumer disappointed. The cake could survive in various degrees, whether room temperature or fridge temperature. Indeed, the taste of the cake would be still delicious even though the cake did not keep in the fridge.

Regarding service, the service of Bandung Makuta emphasizes hospitality. The staff was humble to the consumers, and the delivery service to ease the consumer get Bandung Makuta product without going to the shops was available. This shop prepared restrooms and mushala since typically those were necessary for the consumers. The cleanliness and the hygiene of the shops and the product were checked daily so that the customers could feel comfortable.

Just as Bandung Makuta, Bandung Kunafe branded its shops by doing marketing and conducting special events. The aim was to attract tourists to visit Bandung Kunafe. One of the events can be seen below. 
Figure 1.4 Bandung Kunafe's special event

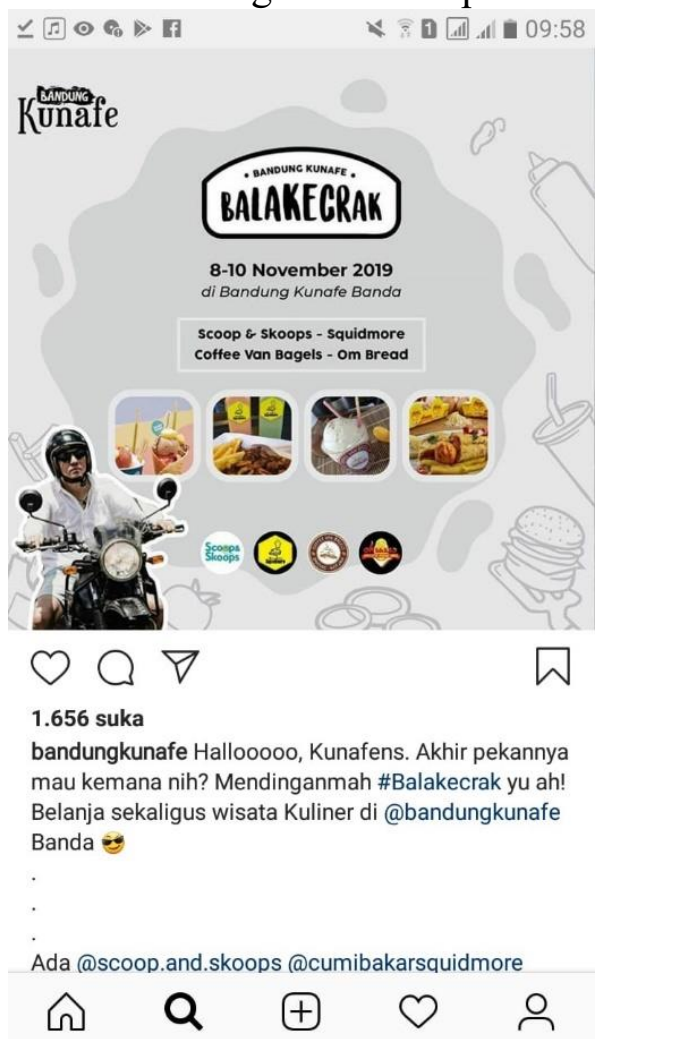

source: Instagram Bandung Kunafe's Instagram

\section{Conclusion}

Bandung Makuta and Bandung Kunafe were the initiators of Bandung nowadays cakes that were capable of attracting many of Bandung residents and tourists. It cannot be separated from the role of Laudya Chintya Bella and Ananda Omesh, who were from Bandung, in branding their shops. Interestingly, they did not only brand the products but also the activities. Bandung Makuta and Bandung Kunafe exercised three methods of Branding, namely advertising, marketing, and public relations. Out of those three components of branding, Bandung Makuta, and Bandung Kunafe, as nowadays cakes, had performed well. It can be seen from the activities of the public relations of those two shops. Not only did they successfully made Bandung residents and tourists interested in purchasing Bandung Makuta's and Bandung Kunafe's products, with taglines, such as \#thisismemorable from Bandung Makuta and \#itisalsomoist from Bandung Kunefa, they also made the customers curious towards the products by doing publicity and promotion through social media, such as Instagram, Line, Facebook, and Youtube.

Furthermore, special events conducted by both Bandung Makuta and Bandung Kunafe also played a significant role. In terms of Bandung Makuta, one of their favorite events was the meet and greet with Laudya Cynthia Bella. Besides, activities such as "Tea-time with Laudya Cynthia Bella," that made many people, in general, and Makuku, in particular, visited Bandung Makuta's stores, and Tabligh Akbar (a grand religious preach) were also significant in giving positive stimulants to society. In addition, they also conducted charity in the form of free public circumcision. Economically unfortunate parents appreciated the event. Likewise, Bandung Kunafe also branded its shop through 
various branding activities. Concerning marketing, this shop conducted direct marketing, both online and offline, by directly visit the shops. For public relations, they informed many customers regarding the products. For special events, Bandung Kunafe preferred to carry out quizzes, giveaways, discounts, and other similar programs.

The study recommends that products produced by Bandung Makuta and Bangung Kunafe be improved, notably the quality and quantity. Also, innovations should be made, whether in terms of the form of the cake, taste, and packaging. For Bandung Makuta, they should be consistent in keeping its communication strategy by exercising positive activities, such as event or sponsorship in various institutions or companies, through social media. Multiply their stores so that more and more customers will buy Bandung Makuta and Bandung Kunafe is also recommended.

\section{References}

A. Sargeant, J. H. \& D. C. W. (2008). Conceptualizing Brand Values in the Charity Sector: the relationship between sector, cause and organization. The Service Industries Journal, 28(5).

ADIAKURNIA, M. I. (2017). Ini Dia 24 Oleh-oleh Kekinian Milik Artis di Berbagai Kota. $\quad$ Retrieved from https://travel.kompas.com/read/2017/07/08/100400527/ini.dia.24.oleholeh.kekinian.milik.artis.di.berbagai.kota

Ardianto, E. (2016). Metodologi Penelitian Untuk Public Relations Kuantitatif dan Kualitatif. Bandung: Simbiosa Rekatama Media.

Ayu, K. (2018a). Instagram Kuenya Ayu. Retrieved from https://www.instagram.com/kuenyaayu/?hl=id

Ayu, K. (2018b). Kuenya Ayu. Retrieved from https://www.facebook.com/Kuenya-Ayu$1999116970357817 /$

Bandung Kunafe. (2019). Bandung Kunafe - Pusat Oleh-Oleh dari Bandung. Retrieved From : https://bandungkunafe.com/

Budiman, I. (2017). Emil Bersyukur Bandung Ditetapkan Sebagai Destinasi Wisata Kuliner Nasional . Retrieved from http://bandung.bisnis.com/read/20170929/13/574517/emil-bersyukur-bandungditetapkan-sebagai-destinasi-wisata-kuliner-nasional

Cake, instagram ceata. (2018). ceata cake. Retrieved from https://www.instagram.com/ceatacake_/

Cake, instagram pevo. (2018). pevo cake. Retrieved from https://www.instagram.com/pevocake/?hl=id

Cake, B. M. (2018). Bandung Madinah Cake. Retrieved from https://www.instagram.com/madinah.cake/?hl=id

Cake, C. (2018). Ceata Cake. Retrieved from https://www.facebook.com/Ceata-Cake331441607308944

Cake, F. B. M. (2018). Bandung Madinah Cake. Retrieved from https://www.facebook.com/BandungMadinahCake/

Cake, F. P. (2018). Pevo Cake. Retrieved from https://www.facebook.com/Pevo-Cake139256040128570/

Cake, I. B. P. (2018). Bandung Princess Cake. Retrieved from https://www.instagram.com/bandungprincesscake/?hl=id

Chiaravella, B., \& Schenk, B. (2015). Branding For Dummies (2nd ed.). New Jersey: John Wiley \& Sons, Inc. 
Cresswell, J. W. (2015). Penelitian Kualitatif \& Desain Riset Memilih di Antara Lima Pendekatan Edisi 3. Yogyakarta: Pustaka Pelajar.

Daisuke Kanama, N. N. (2017). The effects of ingredient branding in the food industry: case studies on successful ingredient-branded foods in Japan. Journal of Ethnic Foods, 4(2), 126-131. Retrieved from https://www.sciencedirect.com/science/article/pii/S2352618117300288

Dian Mardiana. 2017. Bandung Kunafe - Info Harga,Pilihan Menu \& Alamat/Lokasi. Retrieved From : https://tempatwisatadibandung.info/bandung-kunafe/

Elina. (2017). Bandung adalah Surga Bagi Para Kuliner Mania. Retrieved from https://elina.id/bandung-adalah-surga-bagi-para-kuliner-mania/

Facebook Bandung Princess Cake. (2018). Bandung Princess Cake. Retrieved from https://www.facebook.com/bandungprincesscake/.

Goldblatt. (2014). Special Events: Creating and Sustaining a New World for Celebration. New Jersey: John Wiley \& Sons, Inc.

Hakim, A. A. (2018). CHARITY (NILAI DASAR PELAYANAN BERKUALITAS PT. $\begin{array}{llll}\text { ANGKASA } & \text { PURA } & \text { II). } & \text { Retrieved }\end{array}$ https://www.academia.edu/8912273/CHARITY

Hari Susanta Nugraha, Fitrie Ariyanti, D. (2017). PENERAPAN BRANDINGPADA UKM MAKANAN RINGAN DI KABUPATEN JEPARA. Jurnal Administrasi Bisnis, 6(1).

Huda, M. (2012). Kegiatan Sunatan Massal. Retrieved from http://mubtadiulhuda.blogspot.com/2012/01/kegiatan-khitanan-massal.html

Instagram, B. K. (2018). Bandung Kanaya. Retrieved from https://www.instagram.com/bandungkanaya/?hl=id

Instagram, \& Makuta, B. (2018). Bandung Makuta. Retrieved from https://www.instagram.com/bandungmakuta/?hl=id

Instagram, V. (2018). Vincakestory. Retrieved from https://www.instagram.com/vincakestory/?hl=id

Jaya, L. P. P. (2018). Charity. Retrieved from http://pasarjaya.co.id/charity

Kanaya, B. (2018). Bandung Kanaya. Retrieved from https://www.facebook.com/BandungKanaya/

Kasali, R. (2013). Camera Branding Cameragenic VS Auragenic. Jakarta: Gramedia.

Kerry, N. (2018). An Investigation Into How National UK Charities Use Branding and Promotion As A Means of Establishing Donor Loyalty To Increase Income : Using A Case Study of Cancer Research UK. Cardiff Metropolitan University.

Khadijah, S. (2017). Peluang dan Tips Sukses Bisnis Kue Kekinian Ala Artis. Retrieved from https://www.cermati.com/artikel/peluang-dan-tips-sukses-bisnis-kuekekinian-ala-artis

Kunafe, B. (2018a). Bandung Kunafe. Retrieved from https://www.facebook.com/BandungKunafe/

Kunafe, B. (2018b). Bandung Kunafe. Retrieved from https://www.instagram.com/bandungkunafe/?hl=id

Lenka Mikáčováa, P. G. (2014). The role of public relations in branding. Procedia Social and Behavioral Sciences, 110.

Levina, M. (2003). A Branded World Adventures In Public Relations and The Creation Of Superbrands. USA: John Wiley \& Sons.

Lovie, K. A. (2015). Instagram and Branding: A Case Study of Dunkin' Donuts. Elon 
Journal of Undergraduate Research in Communications, 6(2).

Makuta, B. (2018). Produk Makuta. Retrieved from https://www.bandungmakuta.com/

Makuta, F. B. (2018). Bandung Makuta. Retrieved from https://www.facebook.com/bandungmakuta/

Patton, P. (1997). EQ in The Workplace. Singapore: SNP Publishing PTE LTD.

Perbawasari, S. D. dan S. (2016). Membangun Brand Warunk Upnormal Sebagai Warung Indomie Kekinian. Komunikasi Publik Dan Dinamika Masyarakat Lokal, 1-15.

Rachma, Raniawati \& Totok Wahyu Abadi. (2017). Komunikasi Word of Mouth dan Keputusan Pembelian Batik Bangkalan. Jurnal Aspikom, 3(2), 285-295.

Raras Prawitaningrum. (2019). Bandung Kunafe: Berburu Oleh-oleh Khas Jawa Barat Paling Komplet. Retrieved From : https://food.detik.com/tempat-makan/d4603471/bandung-kunafe-berburu-oleh-oleh-khas-jawa-barat-paling-komplet

Ratriyana, Ina Nur. (2019). Ekuitas Merek Lokal Jogja di Mata Generasi Milenials. Jurnal Aspikom 3(6) pp.1163-1181.

S. Moriearty, Mitchell N, W. W. (2011). Advertising (8th ed.). Jakarta: Kencana Prenada Media Group.

Tri Susanto, M. S. D. H. (2017). Analisis Penggunaan Celebrity Brand Ambasador (Studi Kasus Celebrity Brand Ambasador Nagita Slavina, Rafi Ahmad Dalam Gigieatcake). Prosiding Seminar Nasional Riset Terapan, 82-87.

Vincakestory. (2018). Vincakestory. Retrieved from https://www.facebook.com/vincakestory

Wulandari, Suci. (2014). Branding Usaha Dapoer Rendang Riry. Universitas Negeri Padang, 1-17

Yin, R. K. (2014). Studi Kasus Desain dan Metode. Jakarta: PT Raja Grafindo Persada.

Zomato. 2019. Bandung Kunafe. Retrieved From : https://www.zomato.com/id/bandung/bandung-kunafe-riau 